\title{
O feitiço e a feitiçaria capitalista
}

\author{
[ Indigenous witchcraft and the capitalist sorcery
}

\section{Marina Vanzolini ${ }^{\mathrm{x}}$}

RESUMO - Parece ser comum aos pesquisadores da área a percepção de que o Alto Xingu, conjunto multilíngue de povos que habitam a região dos formadores do rio Xingu, vem passando por mudanças significativas associadas ao aumento do afluxo de dinheiro e bens industrializados ao longo da última década ou mais. $\mathrm{O}$ que segue é uma tentativa preliminar de formular uma hipótese sobre um aspecto particular desse contexto - a questão de se há uma relação, e qual, entre essas mudanças e a feitiçaria - com base na etnografia dos Aweti, povo tupi xinguano. Resistir à tentação de achar que nós sabemos melhor do que eles o que está acontecendo, e que sabemos o que é melhor para eles, é também compreender qual a forma, ou uma das formas, que a resistência à captura capitalista pode tomar em seu mundo. PALAVRAS-CHAVE - Aweti; Alto Xingu; feitiçaria; capitalismo. - ABSTRACT - The perception that the Upper Xingu, a multi-linguistic community of indigenous peoples that inhabit the upper reaches of the Xingu river, is going through significant chances associated to the increasing flux of money and manufactured goods over the last decade or more seems to be shared by many researchers working on the area. What follows is a preliminar hypothesis about a particular aspect of this context - the issue of a possible relation between these chances and indigenous sorcery - based on the ethnography of the Aweti, a tupi speaking xinguano people. To resist the temptation to think that we know better them themselves what is going on, and that we know what is best for them, is also to understand what forms the resistance to capitalist capture can take in their world. · KEYWORDS - Aweti; Upper Xingu; sorcery; capitalism

Recebido em 4 de dezembro de 2017

Aprovado em 5 de março de 2018

VANZOLINI, Marina. O feitiço e a feitiçaria capitalista. Revista do Instituto de Estudos Brasileiros, Brasil, n. 69, p. 324-337, abr. 2018.

DOI: http://dx.doi.org/Io.II606/issn.23I6-90IX.voi69p324-337

I Universidade de São Paulo (USP, São Paulo, SP, Brasil). 


\section{O FEITIÇO E A FEITIÇARIA CAPITALISTA}

No começo a terra dos antigos brancos era parecida com a nossa. Lá eram tão poucos quanto nós agora na floresta. Mas seu pensamento foi se perdendo cada vez mais numa trilha escura e emaranhada. Seus antepassados mais sábios, a quem Omama criou e a quem deu suas palavras, morreram. Depois disso, seus filhos e netos tiveram muitos filhos. Começaram a rejeitar os dizeres de seus antigos como se fossem mentiras e foram aos poucos se esquecendo deles. Derrubaram toda a floresta de sua terra para fazer roças cada vez maiores. Omama tinha ensinado a seus pais o uso de algumas ferramentas metálicas. Mas já não se satisfaziam mais com isso. Puseram-se a desejar o metal mais sólido e mais cortante, que ele tinha escondido embaixo da terra e das águas. Aí começaram a arrancar os minérios do solo com voracidade. Construíram fábricas para cozê-los e fabricar mercadorias em grande quantidade. Então, seu pensamento cravou-se nelas e eles se apaixonaram por esses objetos como se fossem belas mulheres. Isso os fez esquecer a beleza da floresta. Pensaram: "Nossas mãos são mesmo habilidosas para fazer coisas! Só nós somos tão engenhosos! Somos mesmo o povo da mercadoria! Podemos ficar cada vez mais numerosos sem nunca passar necessidade! Vamos criar também peles de papel para trocar!". Então fizeram o papel do dinheiro proliferar por toda parte, assim como as panelas e as caixas de metal, os facões e os machados, facas e tesouras, motores e rádios, espingardas, roupas e telhas de metal. Eles também capturaram a luz dos raios que caem sobre a terra. Ficaram muito satisfeitos consigo mesmos. Visitando uns aos outros em suas cidades, todos os brancos acabaram por imitar o mesmo jeito. E assim as palavras das mercadorias e do dinheiro se espalharam por toda a terra dos seus ancestrais. É o meu pensamento. Por quererem possuir todas as mercadorias, foram tomados de um desejo desmedido. Seu pensamento se esfumaçou e foi invadido pela noite ${ }^{2}$.

Só penso nas mercadorias para distribuí-las (Davi Kapenawa, "Paixão pela mercadoria”)3.

2 KOPENAWA, Davi; ALBERT, Bruce. A queda do céu: palavras de um xamã yanomami. São Paulo: Companhia das Letras, 20I5, p. 407.

3 Ibidem, p. 4 I8. 
Desde que iniciei minha pesquisa de campo com os Aweti, em 2004, teria sido impossível ignorar a dependência que eles e seus vizinhos da região haviam desenvolvido em relação a certas coisas do branco - e consequentemente ao dinheiro: andar longas distâncias era uma atividade para a qual apenas as velhas ainda mostravam disposição, homens de qualquer idade e jovens em geral só se locomoviam de bicicleta; a trabalhosa preparação do polvilho de tapioca há muito se valia de bacias e panelas de alumínio; o trabalho na roça, a caça e a pescaria já seriam impensáveis sem instrumentos de metal, espingardas, anzóis e redes. Sem falar das miçangas de vidro tchecas (e não outras), elemento fundamental da ornamentação corporal de homens e mulheres, ao lado dos tradicionais colares de caramujo. Além das roupas, sandálias havaianas, remédios, aparelhos de som, DVDs. Nada disso me espantou quando cheguei à aldeia. Felizmente, eu havia sido preparada por meus mestres ${ }^{5}$ para compreender que a roupa não faz de um índio menos índio, e que as transformações dos mundos indígenas só podem ser entendidas como processos dos quais os índios são sujeitos, e não objetos. Se os mundos indígenas mudam - como todos os mundos, aliás -, só podem mudar em seus próprios termos.

Creio ser comum aos pesquisadores da região, contudo, a percepção de que o Alto Xingu vem passando por mudanças significativas e, para nós, assustadoras, ao longo da última década ou mais, em grande parte associadas à entrada de programas de transmissão de renda como o Bolsa Família e a aposentadoria. Como sabemos, o dinheiro tem o mau costume de produzir sua própria necessidade. $\mathrm{O}$ acesso regular ao dinheiro não só permitiu, mas exigiu o acesso regular à cidade. Abriu-se a possibilidade, e o desejo, de se comprar mais e melhores coisas. Mudaram também algumas relações na aldeia: o pagamento dos xamãs agora pode incluir, além dos tradicionais colares de caramujo e miçanga, uma moto ou televisão, e mesmo dinheiro. Um número razoável de jovens tem escolhido trabalhar na cidade por um salário, refletindo, creio, uma mudança nas expectativas entre parentes. Ser um bom pescador talvez já não seja suficiente, como outrora, para conquistar uma noiva xinguana.

Parece que estamos diante, enfim, da abertura acelerada de um mundo até pouco tempo relativamente fechado, e que contava com a provisão racionada de bens industrializados como um modo de controlar suas fronteiras. Antes mesmo da entrada dos benefícios sociais, esse processo é efeito do enfraquecimento progressivo da política instaurada na década de I960 pelos irmãos Villas-Bôas,

4 Adoto a tradução nativa mais comum para os não índios.

5 Ver: VIVEIROS DE CASTRO, Eduardo. Etnologia brasileira. In: MICELLI, Sergio (Org.). O que ler na ciência social brasileira (I970-I995). Volume I: Antropologia, I999, p. I09-223. São Paulo: Sumaré/Anpocs; SAHLINS, Marshall. Metáforas históricas e realidades míticas. Rio de Janeiro: Jorge Zahar, 2008; GOW, Peter. Of mixed blood: kinship and history in Peruvian Amazonia. Oxford: Clarendon Press, I99I; e as discussões de Lévi-Strauss sobre temporalidade, mito e a noção de sociedades frias e quentes, por exemplo em: LÉVI-STRAUSS, Claude. Antropologia estrutural. Rio de Janeiro: Tempo Brasileiro, 2003; LÉVI-STRAUSS, Claude. O pensamento selvagem. Campinas: Papirus,I99o; LÉVI-STRAUSS, Claude. Antropologia estrutural II. Rio de Janeiro: Tempo Brasileiro, I993; LÉVI-STRAUSS, Claude. Mitológicas I - O cru e o cozido. Tradução Beatriz Perrone-Moisés. Rio de Janeiro: Cosac Naify, 2004; LÉVI-STRAUSS, Claude. História de lince. São Paulo: Companhia das Letras, I993. 
figuras centrais no processo de criação do então Parque Nacional do $\mathrm{Xingu}^{6}$ e seus primeiros administradores. Contam os Aweti que os Villas-Bôas os impediam de sair da área demarcada, alegando que os fazendeiros da região iriam envenená-los. Os irmãos indigenistas acreditavam que a formação de algumas lideranças indígenas, instruídas nas cidades sobre a língua e o modo de vida dos brancos, era essencial para garantir aos xinguanos melhores condições nas relações com a chamada "sociedade envolvente". O efeito colateral desse projeto foi que a gente comum das aldeias (ou assim me contaram os Aweti) sentia-se prisioneira em sua própria terra. Mas quem poderia julgar a intenção dos Villas-Bôas? O mundo lá fora não estava (e está) de fato decidido a exterminar os xinguanos?

Nesse cenário, talvez espante que os Aweti não estejam formulando, ou não com muita ênfase, um discurso crítico ao mundo branco e a nossa "paixão pela mercadoria” - para falar como Davi Kopenawa e outras lideranças indígenas atuais. Ao contrário, os Aweti com quem conversei sobre isso não pareciam temer as mudanças produzidas pela introdução do dinheiro em suas aldeias. Seriam então ingênuos frente ao poder avassalador desse mundo que ameaça engoli-los, com sua monótona lógica da necessidade de consumo?

A relação dos xinguanos com o dinheiro e a cidade é tema de investigação de duas antropólogas trabalhando na região, cujas pesquisas representam uma bem-vinda contribuição à nossa compreensão da questão7. O que segue é uma tentativa preliminar de formular uma hipótese sobre um aspecto particular desse contexto - a questão de se há uma relação, e qual, entre as mudanças implicadas pela crescente entrada de dinheiro e bens industrializados no Alto Xingu e a feitiçaria8. O que proponho, portanto, é um debate com minhas próprias elaborações sobre a feitiçaria xinguana, tal como pude aprender dos Aweti e venho desenvolvendo ao longo de uma pesquisa iniciada em 2006 .

Mais do que uma pergunta, a questão da relação entre capitalismo e feitiçaria parece uma resposta, já mobilizada para analisar contextos similares em outras partes do mundo ${ }^{\mathrm{Io}}$. A proliferação da feitiçaria, poderíamos supor, é o efeito da

6 Hoje Parque Indígena do Xingu (PIX).

7 NOVO, Marina Pereira. Esse é o meu patikulá: uma etnografia do dinheiro e outras coisas entre os kalapalo de Aiha. Tese (Doutorado em Antropologia Social). Universidade Federal de São Carlos, 20I7; HORTA, Amanda. Indígenas em Canarana: notas citadinas sobre a criatividade parque-xinguana. Revista de Antropologia, São Paulo, v. 6o, n. I, p. 2I6-24I, maio 20I7. http://dx.doi.org/Io.II606/2I79-0892.ra.20I7.I32074.

8 Seguindo a tradução nativa, traduzo por feitiço o termo aweti tupiat. De modo geral, o termo designa flechas minúsculas que, atadas a exúvias da vítima, provocam seu adoecimento, ou podem ser lançadas diretamente contra ela. Para uma descrição detalhada de seu funcionamento, e um comentário sobre a opção de tradução, ver: VANZOLINI, Marina. A flecha do ciúme. O parentesco e seu avesso segundo os Aweti do Alto Xingu. São Paulo: Terceiro Nome, 2015 .

9 Ibidem.

Io Para uma crítica a esse tipo de abodagem, ver: KAPFERER, Bruce. Introduction: outside all reason - magic, sorcery and epistemology in anthropology. In: (Ed.). Beyond rationalism. Rethinking magic, witchcraft and sorcery. New York, Oxford: Berghahn Books, 2002, p. I-30. 
desorganização social causada por um fator externo, político ou econômico, sendo traduzida pelos índios como feitiço. Se isso fosse verdade, seria necessário admitir que os Aweti não entendem a verdadeira natureza do que os afeta; não entendem sequer de onde vem o problema, cegamente acusando-se uns aos outros. Mas essa é uma resposta à qual eu gostaria de resistir, pois ela não me parece fazer jus ao pensamento xinguano. Resistir à tentação de achar que nós sabemos melhor do que eles o que está acontecendo, e que sabemos o que é melhor para eles, é também compreender qual a forma, ou uma das formas, que a resistência ao aparelho de captura capitalista pode tomar em seu mundo. Seria possível imaginar a feitiçaria como uma resposta positiva ao feitiço da mercadoria, e não um entendimento pobre de seus efeitos? Algumas ideias de Isabelle Stengers e Philippe Pignarre ${ }^{\text {II }}$ sobre a feitiçaria capitalista me forneceram pistas para começar a pensar essa questão.

\section{O FEITIÇO VEM DE PERTO}

Os Aweti são um povo falante de língua tupi que vive às margens dos rios Curisevo e Tuatuari, dois afluentes do rio Culuene, principal formador do Xingu, ao norte do estado do Mato Grosso, no planalto central brasileiro. Os povos indígenas que habitam essa região, que ficou conhecida na literatura etnológica como Alto Xingu, foram descritos pela primeira vez por Karl von den Steinen ${ }^{\mathrm{T} 2}$, viajante alemão que esteve lá em fins do século XIX. Steinen encontrou então uma situação bastante similar à que conhecemos hoje: povos falantes de línguas distintas, em sua maioria pertencentes a três dos principais troncos e famílias linguísticas presentes no Brasil (karib, aruák e tupi), convivendo num sistema de trocas rituais, matrimoniais e econômicas que define as fronteiras do que Eduardo Galvão ${ }^{\mathrm{I3}}$ veio a denominar, bem mais tarde, "área cultural do uluri", ou seja, um coletivo marcado por um conjunto de padrões éticos e estéticos compartilhados.

Só se morre de feitiço no Alto Xingu. Fato comum em outras partes da Amazônia (e alhures), o adoecimento e a morte são entendidos ali como resultado da ação intencional de um sujeito, humano ou não humano. Quando alguém adoece, portanto, a pergunta pertinente é menos “o que o está matando?”, mas antes “quem o está matando?”. É para a identificação desse agente que se volta boa parte da atividade xamânica. O diagnóstico envolve transes visionários do xamã, a interpretação de sonhos e visões do doente, além da constante elaboração de hipóteses que, rememorando suas atividades recentes, permitam explicar os motivos e meios da agressão que provoca o adoecimento. Ainda que certos animais também possam fazer feitiços ou causar o adoecimento de alguém capturando sua alma, doenças

II PIGNARRE, Philippe; STENGERS, Isabelle. La sorcellerie capitaliste. Pratiques de désenvoutement. Paris: La Découverte, 2005.

I2 STEINEN, Karl Von Den. Entre os aborígenes do Brasil Central. Separata renumerada da Revista do Arquivo, $\mathrm{n}$. XXXIV a LVIII, São Paulo, Departamento de Cultura, I940.

I3 GALVÃO, Eduardo. Cultura e sistema de parentesco das tribos do alto rio Xingu. In: Encontro de

sociedades. Índios e brancos no Brasil. Rio de Janeiro: Paz e Terra, I979, p. 73-II9. 
graves e adoecimentos são sempre provocados por um agente humano, geralmente alguém social e geograficamente próximo da vítima.

A feitiçaria no Alto Xingu é altamente secreta. Ninguém assume ser feiticeiro, e um feiticeiro reconhecido frequentemente era executado, no passado, quando os familiares de uma vítima conseguiam reunir um grupo suficientemente grande para armar uma emboscada contra o agressor. Dificilmente, no entanto, esse veredicto corresponde a uma opinião coletiva: a família de um homem executado, ou mesmo de um que tenha sido apenas acusado reiteradamente de feitiçaria, vai certamente defender sua inocência, contra-acusando, por sua vez, os acusadores de fofoqueiros, agressivos, gente ruim. Não existe um mecanismo universal de determinação de culpados - mesmo a vingança por execução é sempre um negócio de família. Vista de fora, a feitiçaria se apresenta como um problema de ponto de vista: o que é feitiço, para uns, é vingança contra uma feitiçaria injustamente suposta, para outros, ou simplesmente o ataque de um espírito, para um terceiro.

Invisível, ao menos para o antropólogo estrangeiro, a feitiçaria xinguana tendeu a ser tomada como "linguagem" para a resolução de questões que lhe escapavam, como se só pudesse ser entendida se remetida a algo ausente - deliberadamente velado ou inconsciente - dos discursos nativos sobre o feitiço. Esse algo, evidentemente, só poderia ser a política, entendida em seu sentido mais estrito. Dessa forma, não a feitiçaria (a qual, como todo cidadão ilustrado haveria de concordar, não pode existir), mas as acusações de enfeitiçamento (essas sim, bem reais ${ }^{\mathrm{I}}$ ) foram via de regra interpretadas como armas estratégicas na disputa pelo controle da chefia aldeã. Uma versão especialmente elaborada dessa tese associa a feitiçaria à desintegração de linhagens de chefes em decorrência da depopulação provocada pelo contato, tomando sua proliferação como resultado da degeneração de um sistema político que, se deixado à sua própria sorte, operaria de forma harmoniosa, com uma hierarquia baseada na transmissão hereditária de posições de chefia, tendendo mesmo à crescente centralização ${ }^{\mathrm{I5}}$.

Discutindo comigo casos de enfeitiçamento, contudo, os Aweti jamais traçaram uma relação direta entre o feitiço e a disputa por posições políticas. Apesar de afirmarem geralmente que os feiticeiros agem por pura maldade, eles sempre buscavam explicações que pudessem justificar um ou outro enfeitiçamento em particular - um prato de comida negado, vingança por suspeita de adultério, inveja dos filhos saudáveis ou da roça de outrem, ciúme pelo cuidado dispensado a outro etc. A feitiçaria xinguana sempre me pareceu, assim, estar ligada às expectativas e frustrações, aparentemente inevitáveis, da vida entre parentes.

Ciúme-inveja, sentimentos designados por um único termo na língua aweti (temyzotu), são associados ao feitiço não só nas conversas cotidianas, mas também no mito que narra a origem conjunta de ambos, sentimento e malefício. A história

I4 Note-se por favor a ironia da minha formulação.

I5 Minha leitura da tese de Heckenberger. Ver: HECKENBERGER, Michael. The ecology of power. Culture, place and personhood in the Southern Amazon A.D. I000-2000. Nova York: Routledge, 2005. Para uma apresentação mais detalhada dessa crítica ver também: VANZOLINI [Figueiredo], Marina. Imagens do poder: a política xinguana na etnografia. Cadernos de Campo, São Paulo, n. I7, 2008, p. 89-Io9. 
remonta a uma sequência de eventos em que os gêmeos demiurgos Sol e Lua recebem de diferentes gentes-animais atributos da vida humana atual relacionados aos ciclos fisiológicos - a flatulência, o sono, a ereção masculina -, eventos associados à instauração das periodicidades curtas da biologia humana e à consequente regulação da vida ${ }^{\mathrm{I}}$. A última aquisição desse ciclo é o ciúme, temyzotu, recebido de coruja (uzyt), que resulta na desconfiança desmedida entre irmãos (Sol suspeita que Lua namore sua esposa, e adoece) e na violência entre parentes (irado por passar a sentir ciúme de sua própria esposa, o avô dos gêmeos, Mawutsini, se vinga de Sol enfeitiçando-o). De uma série labiríntica de episódios em que Sol, Lua e seu avô Mawutsini se alternam nas posições de ciumento-enfeitiçador, vítima do feitiço e xamã curador, depreende-se que, depois do advento do ciúme, nunca mais foi possível livrar-se do feitiço. A associação desse feito às conquistas anteriores explicita que a instauração dos pequenos ciclos que regem a vida humana não pode ser dissociada daquilo que determina seu fim.

Outro episódio da saga mítica de Sol e Lua ajuda a evidenciar a relação entre parentesco e feitiçaria. Ainda crianças, os gêmeos demiurgos não cessam de importunar o avô Wamutsini, pedindo-lhe comida. Apesar de possuir uma grande roça e uma produção considerável de polvilho (mi'ak), o avô só alimenta os netos com "massa" (mie'e), um subproduto insosso do processamento da mandioca. Ao descobrirem a avareza, os netos se vingam produzindo imagens-feitiços de caititus, tatus e veados para comerem a plantação do avô. Ainda que apresente Wamutsini como um mau parente, a história enfatiza também a chateação constante dos netos, sua insaciabilidade: Atu, jumem! Atu, pira'yt! ("Vovô, queremos beiju! Vovô, queremos peixe!”), repetem insistentemente os gêmeos. Fica-se sem saber quem está certo e quem está errado, e o que resta é a sensação de que não é fácil viver a contento entre parentes.

\section{Para QUe SERVem as COISAS}

Já ouvi muitos Aweti dizendo que os índios brigam por causa das coisas de branco, que antes da chegada dos brancos não havia tanta briga - e quase toda briga séria entre eles envolve feitiçaria. Presenciei a mudança de um chefe e sua família da aldeia como resultado de um longo período de tensão que teve como um de seus temas principais uma velha caminhonete doada por um linguista alemão. $\mathrm{O}$ carro, recebido pela comunidade em troca da pesquisa linguística, era dirigido e cuidado pelo chefe. $O$ fato de haver tomado a palavra no pedido da doação justificava, do seu ponto de vista, que o carro ficasse sob seu controle e pudesse ser usado por sua família para pescarias ou viagens particulares. $O$ automóvel era disponibilizado também, é claro, para atividades coletivas da aldeia, ou para transportar passageiros de

I6 Os episódios que narram a aquisição do sono e da ereção, ligados à alternância dia/noite e à possibilidade de alternância geracional, respectivamente, enfatizam em seu desfecho o estabelecimento de horas definidas para o trabalho, o descanso e o sexo. A aquisição da flatulência é associada ao bom termo do ciclo digestivo, pois antes dela as pessoas tampouco defecavam, apenas exalavam um bafo fedorento. 
outras famílias em ocasiões especiais. Do ponto de vista de outras pessoas da aldeia, contudo, o chefe havia se apropriado de um bem da comunidade (termo utilizado em português, ponto que discuto adiante), problema insistentemente comentado nos ambientes domésticos. Mas, ainda que esse fosse um forte elemento de crítica velada ao chefe, não foi o único fator de tensão que culminou com sua mudança, e seguramente não o mais explícito. Um casamento malsucedido entre uma de suas filhas e o filho de uma família influente da aldeia, com as fofocas sobre fofocas que o acompanharam, claramente contribuiu para a deterioração de suas relações. E foi o vaivém de acusações e acusações de acusações de feitiçaria ${ }^{17}$ envolvendo membros de sua família e outros moradores da aldeia que terminou por tornar insustentável sua permanência.

Se é verdade que as coisas do branco complicaram as relações aldeãs, aumentando os pontos de tensão, não é fácil discernir a diferença representada por esses objetos no mundo xinguano, onde mesmo aquilo que identificamos mais claramente como "cultura indígena" é um atributo do exterior (um ponto ressaltado por Novo em sua tese recente sobre os Kalapalor8). Grande parte dos relatos "míticos" descrevem como rituais, cantos, conhecimentos agrícolas e adornos corporais foram recebidos de gentes-pássaro, gentes-peixe, gentes-onça etc. E isso não se restringe ao passado longínquo. A produção do sal vegetal, especialidade aweti no contexto xinguano, envolve continuamente a negociação com seres não humanos, donos ${ }^{19}$ do aguapé, sua matéria-prima. A confecção de colares de caramujo pelos povos karib xinguanos, que outrora envolvia a negociação com os donos não humanos do caramujo, hoje requer a negociação com os Xavante, de quem se compra a matéria-prima na cidade. Essa origem exterior, bem como as dificuldades envolvidas na produção ou aquisição de cada uma dessas coisas, dita seu valor. Os Aweti explicam, por exemplo, que o sal vegetal é caro porque sua produção é cheia de riscos e sacrifícios: as lagoas de onde se retira o aguapé, matéria-prima do sal, são povoadas de peixes elétricos e outros seres monstruosos. Além disso, o processo de produção é longo e envolve, em cada etapa, diferentes privações físicas; diz-se que antigamente a produtora de sal que não observasse todas as regras poderia mesmo morrer, por vingança do sal, que os Aweti reconhecem como um tipo de gente.

Colares, panelas, sal, e outros bens de valor não são apenas utilizados como utensílios domésticos ou adornos corporais, mas podem ser dados em troca de outros bens, além de ser continuamente disponibilizados para tratamentos xamânicos, que sempre envolvem pagamentos de alto valor. Há, portanto, uma forte correspondência entre a vida das pessoas e os bens que circulam no Alto Xingu: adquirir um bem pode custar uma vida, mas os bens são dados para salvar vidas. Isso inclui tanto objetos "tradicionais" quanto aqueles mais recentemente incorporados ao mundo xinguano - panelas grandes de alumínio e miçangas de vidro figuram hoje como

I7 Acusar reiteradamente outros de feitiçaria, ou acusá-los de fofoqueiros, é um ato tão socialmente problemático quanto fazer feitiços ou fofocas, do ponto de vista dos Aweti. Ver: VANZOLINI, Marina, 20I5, op. cit.

I8 NOVO, Marina, op. cit.

I9 Ver adiante algumas implicações da noção aweti itat, traduzida por eles pelo termo português dono. 
elementos comuns nas trocas cerimoniais e pagamentos xamânicos, que também podem incluir aparelhos de televisão, motos etc.

O que diferencia, então, os bens do branco das coisas valiosas que sempre circularam no Alto Xingu como elementos definidores do modo de vida xinguano? Ao analisar o impacto do aumento da circulação de dinheiro e coisas do branco entre os Kalapalo, povo karib xinguano, Marina Novo ${ }^{20}$ ressalta a incorporação de duas palavras da língua portuguesa ao vocabulário indígena: de um objeto comprado com o dinheiro do Programa Bolsa Família, por exemplo, os Kalapalo dizem que é seu patikulá, distinguindo-o de bens ditos da comunidade (usando ambos os termos em português) como carros ou geradores comprados com dinheiro de projetos de ONGs e pesquisadores. Como bem nota a autora, a inclusão desses dois vocábulos exógenos deve nos dizer algo sobre as mudanças recentes no mundo kalapalo e xinguano. Ainda que as coisas de branco possam ser incorporadas aos circuitos tradicionais de troca ou pagamento, a etnografia de Novo sugere que a mudança representada por sua introdução massiva reside no modo de circulação que elas inspiram. Tudo se passa como se os objetos manufaturados carregassem consigo uma lógica de posse estranha ao mundo xinguano, obrigando à distinção entre o comunitário e o particular num regime em que tradicionalmente nenhuma dessas noções tem sentido: coisas tão coletivas quanto aldeias, rituais e caminhos têm donos no mundo xinguano, pessoas que se distinguem por terem iniciado ou simplesmente por cuidarem de algo; por outro lado, coisas pessoais, como colares, panelas ou roupas, circulam continuamente entre pessoas, seja quando trocados por bens equivalentes, seja quando são oferecidos para ajudar a pagar o tratamento xamânico de um parente, seja ao serem apenas dados de presente a um parente, namorado ou amigo formal, com perspectiva de retorno a longo prazo ${ }^{2 \mathrm{I}}$. Bens "comunitários", como a caminhonete recebida pelos Aweti do pesquisador estrangeiro, confundem esse esquema, tornando a figura do dono problemática ou equívoca. No caso aweti que relatei, o chefe e os demais moradores da aldeia já não pareciam concordar quanto ao regime ideal de cuidado e uso daquele bem, o primeiro queixando-se por ter de cuidar sozinho do veículo, os demais reclamando que ele o usava como se fosse seu, e quando utilizavam a noção de dono era apenas com ironia, implicando que ele já não se comportava com um dono xinguano, e sim como um dono não índio. Ainda que esse caso possa ser lido à luz

20 NOVO, Marina, op. cit.

2I Marina Novo (op. cit.) desenvolve com muito maior minúcia o problema da definição dos donos xinguanos (itat, em aweti; oto, na língua kalapalo), figura que organiza relações de diversas (e inseparáveis) ordens: política, ritual, cosmológica. Ver também: BARCELOS NETO, Aristóteles. Apapaatai. Rituais de máscaras no Alto Xingu. São Paulo: Edusp, 2008; GUERREIRO JR., Antonio. Ancestrais e suas sombras. Uma etnografia da chefia kalapalo e seu ritual mortuário. Campinas: Unicamp, 20I5; e VANZOLINI, Marina, 20I5, op. cit. 
de uma filosofia política xinguana, como argumentei em outra ocasião ${ }^{22}$, é evidente que o problema das coisas de branco ultrapassa o âmbito da chefia, como explicita a insistência dos Kalapalo no caráter patikulá de certos bens, registrada por Marina Novo.

Mas ainda é preciso esclarecer o que distingue os bens patikulá de outros bens pessoais quaisquer para os Kalapalo e seus vizinhos xinguanos, se nos permitirmos, a título exploratório, a extrapolação de experiências locais para o âmbito regional. Como descobri rapidamente em minha convivência com os Aweti, é difícil para um branco encontrar uma justificativa plausível para não se desfazer de um objeto na aldeia, trocando ou simplesmente dando-o de presente a quem o pede. Negativas como "foi um presente de meu avô", ou "gosto muito disso" suscitavam comentários que denunciavam a inconsistência de meus argumentos, do ponto de vista aweti: "você arruma outro, Marina!". Certa vez um amigo me ensinou como deveria proceder em situações assim: "você deve dizer ite ypó, isso é meu patikulá"23, instruiu-me. A noção aweti ypó designa um tipo de relação que não se confunde, se bem entendo, com aquela associada ao termo itat, esta última geralmente traduzida pelos Aweti por dono. Como evidenciado na expressão waraju eypó, "coisa de índio", que os Aweti usam para distinguir o feitiço indígena das doenças de branco, o termo -ypó define algo como sendo próprio ou característico de alguém, mas não sua propriedade. Enquanto a condição de dono qualifica o sujeito como zelador daquilo de que é dono, implicando sua posição de provedor em relação a outros sujeitos não donos do mesmo bem, o termo ypó marca, me parece, a radical inalienabilidade do objeto, já que ninguém pode se desfazer daquilo que se define como sendo seu próprio ${ }^{24}$. Talvez por isso o conceito tenha parecido apropriado aos Aweti, ou ao amigo que me aconselhava naquele momento, para dar conta do estranho apego que eu revelava com relação a minhas coisas. Coisas particulares seriam aquelas de que não queremos dispor para trocar ou compartilhar? Mas é possível escapar à lógica do parentesco, que define relações em termos da circulação de bens, comida e palavras?

"Só penso nas mercadorias para distribuí-las", disse Davi Kopenawa ${ }^{25}$, criticando nossa relação de posse com os objetos aos quais nos agarramos, apaixonados,

22 Apresentei detalhes do caso num trabalho anterior (VANZOLINI, Marina. Eleições na aldeia, ou o Alto Xingu contra o Estado?. Anuário Antropológico, I/20II, 20II, p. 3I-54.). O desfecho dramático, e inusual para o contexto xinguano, dos desentendimentos em torno da caminhonete assim como os demais episódios que culminaram com a mudança da família do chefe indicam que fatores contingenciais, como a história e personalidade particulares desse homem, foram decisivos para o rompimento das relações aldeãs. De todo modo, entendo haver uma tendência, inerente à filosofia política xinguana, mas agravada no contexto atual em que os chefes tendem a monopolizar o acesso a certos brancos e seus valiosos bens, de que o chefe não corresponda às expectativas de generosidade dos demais habitantes da aldeia.

23 Mantenho a grafia proposta por Novo (op. cit.) para o neologismo, pois corresponde também à pronúncia aweti.

24 A distinção desses conceitos merece maior investigação, e sua qualificação em termos da alienabilidade do objeto não me parece totalmente satisfatória, já que, quanto às coisas que circulam, seu valor reside em sua origem específica, isto é, no fato de terem um dono. Nesse sentido também se pode dizer que são inalienáveis.

25 KOPENAWA, Davi; ALBERT, Bruce, op. cit. 
como se fossem esposas (ou maridos). Tenho certeza de que os Aweti concordariam com isso. Mas tudo indica que os extraordinários bens dos brancos complicam ou confundem um esquema relacional que no entanto, dizem os mitos, nunca foi livre de mal-entendidos e frustrações. Não creio, contudo, que isso faça deles vítimas alienadas da predação do capital.

\section{A FEITIÇARIA CONTRA O CAPITALISMO}

Se os Aweti associam a avalanche de objetos manufaturados e dinheiro em suas vidas a histórias de enfeitiçamento, é porque esses objetos suscitam expectativas e sentimentos similares àqueles mobilizados nas relações de parentesco em geral, ao mesmo tempo que talvez despertem o desejo de uma nova forma de relação entre pessoas e coisas, um outro tipo de posse. Mas o desdobramento desse equívoco em casos de feitiçaria confirma que importam as relações, não as coisas. Não creio que os Aweti estejam cegos à origem real do problema que estariam vivendo, mas que afirmem dessa forma em que termos as mudanças atuais lhes afetam e importam.

É por isso que, quando o assunto não era feitiçaria, mas o pagamento dos xamãs em dinheiro, ou o fato de que agora quase todas as casas possuem um aparelho de televisão, por exemplo, os Aweti com quem conversei não pareciam se preocupar com essas novidades, como se acreditassem que algo essencial não fosse ameaçado por elas. Creio que esse algo são as relações, não apenas entre humanos, mas também com os não humanos (e brancos) cuja presença é essencial para sua vida. Seu medo é menos a transformação, inerente a seu modo de existência, que a aniquilação pelo inimigo ${ }^{26}$. É comum as pessoas sonharem com suas terras sendo bombardeadas pelos brancos, ou com a chegada de uma gripe fatal.

É num sentido pragmático que Isabelle Stengers e Philippe Pignarre ${ }^{27}$ propõem identificar o capitalismo como um sistema feiticeiro. Não se trata de defini-lo em sua essência mas de, como um etólogo, "reconhecer a besta pelo que ela pode fazer". Se o que caracteriza o capitalismo é sua capacidade de capturar nossa imaginação, condenando-nos a aceitar a "evidência" das alternativas infernais impostas pelo capital, nomeá-lo feitiçaria nos obriga a desenvolver técnicas de proteção ou desenfeitiçamento que permitam a concepção de novas maneiras de viver neste mundo. Essencial a essas técnicas de resistência é a recusa do jogo da verdade contra o erro, aliada do capitalismo em seus rumos aparentemente inelutáveis. Resistir ao capitalismo é admitir que não há questão econômica, científica, ou de outra ordem que possa ser colocada fora da política, fora de debate; que nenhuma razão pode justificar uma decisão sem que se dê ouvidos às questões colocadas por cada um daqueles que serão afetados por ela. O desenfeitiçamento proposto por Stengers e Pignarre implica uma nova relação com a verdade, inclusive aquela dos

\footnotetext{
26 Ainda que o medo da perda das tradições possa se apresentar também para os xinguanos, como registra

Marina Novo (op. cit.) entre os Kalapalo.
}

27 PIGNARRE, Philippe; STENGERS, Isabelle, op. cit. 
revolucionários. É preciso complicar cada questão, não simplificar, dizem os autores. Não há resposta definitiva, nem critério universal.

Afirmando que sua principal preocupação são as relações entre pessoas próximas, e não as razões do capital - mesmo quando trabalham por um salário ou discutem por um carro - os Aweti me parecem mostrar que não foram capturados em sua imaginação. Mas isso não é tudo. $\mathrm{O}$ fato de que a feitiçaria só pode ser reconhecida através de discursos e vestígios, como comentei acima, talvez não seja banal. Quando alguém adoece ou morre na aldeia, pessoas próximas da vítima não param de avançar explicações que elas mesmas caracterizam como "tentativas" sobre o que está acontecendo: "estamos só procurando [a verdade]", explicavam-me os Aweti muitas vezes quando eu começava a questioná-los sobre o que pensavam de fato ter acontecido. Há uma forma particular das conversas sobre feitiçaria que me parece levar em conta o fato de que uma acusação é sempre provisória, mesmo quando fundada numa visão xamânica - pois os Aweti não deixam de considerar a possibilidade de que os xamãs eventualmente se enganem, ou sejam incapazes de ver o que se passa.

Seria absurdo dizer que para um Aweti que não importa saber quem é o verdadeiro feiticeiro que está matando um parente; muito pelo contrário, isso é quase tudo o que importa saber, e as pessoas passam muito tempo de suas vidas especulando sobre os pensamentos alheios (talvez como nós). Mas estamos diante de um mundo que não inventou para si mesmo instâncias de averiguação dos fatos e, sobretudo, não se devota ao problema da determinação absoluta, física ou metafísica, das coisas. $\mathrm{Na}$ prática, histórias de enfeitiçamento têm sempre uma multiplicidade de versões sobre as quais as pessoas especulam sem muito embaraço. $\mathrm{O}$ que parecia ser verdadeiro há pouco talvez agora não faça mais sentido, e não há nenhum escândalo lógico nisso. Essa forma de pensar, que em outros tempos foi tomada como prova da irracionalidade dos chamados povos primitivos, talvez constitua a própria força do seu pensamento: ainda que em termos bem diferentes, ela também recusa, como as técnicas de desenfeitiçamento defendidas por Stengers e Pignarre, a dominação de uma lógica única, e portanto a lógica da dominação, seja pelo capital ou pelo Estado.

Mas ninguém imaginaria que a história acaba aqui. Se a feitiçaria pode representar um modo de resistência da vida xinguana frente à devoração pela lógica do capitalismo, é certo que muitas outras resistências, em discursos e atos, estão sendo criadas neste mesmo momento. Pois é preciso dizer que os Aweti e seus vizinhos xinguanos sentem diariamente a ameaça do capital ao seu modo de vida - sob a forma das invasões de seu território, da construção de barragens que afetam o fluxo dos rios, da contaminação do solo e da água, das mudanças climáticas que afetam o regime de chuvas etc. - e contra isso lutam com todas as suas armas. 
MARINA VANZOLINI é professora de Antropologia Social da Faculdade de Filosofia, Letras e Ciências Humanas da Universidade de São Paulo (FFLCH/ USP) e pesquisadora do Centro de Estudos Ameríndios (CEstA/USP).

E-mail: marinavanzolini@gmail.com

\section{REFERÊNCIAS BIBLIOGRÁFICAS}

BARCELOS NETO, Aristóteles. Apapaatai. Rituais de máscaras no Alto Xingu. São Paulo: Edusp, 2008. GALVÃO, Eduardo. Cultura e sistema de parentesco das tribos do alto rio Xingu. In: . Encontro de sociedades. Índios e brancos no Brasil. Rio de Janeiro: Paz e Terra, I979, p. 73-ᄑ9.

GOW, Peter. Of mixed blood: kinship and history in Peruvian Amazonia. Oxford: Clarendon Press, I99I. GUERREIRO JR., Antonio. Ancestrais e suas sombras. Uma etnografia da chefia kalapalo e seu ritual mortuário. Campinas: Unicamp, 2015.

HECKENBERGER, Michael. The ecology of power. Culture, place and personhood in the Southern Amazon A.D. Io00-2000. Nova York: Routledge, 2005.

HORTA, Amanda. Indígenas em Canarana: notas citadinas sobre a criatividade parque-xinguana. Revista de Antropologia, São Paulo, v. 6o, n. I, maio 20I7, p. 2I6-24I. http://dx.doi.org/Io.II606/2I79-0892. ra.20I7.I32074.

KAPFERER, Bruce. Introduction: Outside all reason - magic, sorcery and epistemology in anthropology. In: (Ed). Beyond rationalism. Rethinking magic, witchcraft and sorcery. New York, Oxford: Berghahn Books, 2002, p. I-30.

KOPENAWA, D.; ALBERT, B. A queda do céu: palavras de um xamã yanomami. São Paulo: Companhia das Letras, 2015.

LÉVI-STRAUSS, Claude. O pensamento selvagem. Campinas: Papirus, I990. . Antropologia estrutural II. Rio de Janeiro: Tempo Brasileiro, I993. . História de lince. São Paulo: Companhia das Letras, I993. . Antropologia estrutural. Rio de Janeiro: Tempo Brasileiro, 2003. . Mitológicas I - O cru e o cozido. Tradução Beatriz Perrone-Moisés, Rio de Janeiro: Cosac Naify, 2004. NOVO, Marina Pereira. Esse é o meu patikulá: uma etnografia do dinheiro e outras coisas entre os kalapalo de Aiha. Tese (Doutorado em Antropologia Social). Universidade Federal de São Carlos, 2017.

PIGNARRE, Philippe; STENGERS, Isabelle. La sorcellerie capitaliste. Pratiques de désenvoutement. Paris: La Découverte, 2005.

SAHLINS, Marshall. Metáforas históricas e realidades míticas. Rio de Janeiro: Jorge Zahar, 2008.

STEINEN, Karl von den. Entre os aborígenes do Brasil Central. Separata renumerada da Revista do Arquivo, n. XXXIV a LVIII, São Paulo, Departamento de Cultura, I940.

VANZOLINI [Figueiredo], Marina. Imagens do poder: a polícia xinguana na etnografia. Cadernos de Campo. São Paulo, n. I7, 2008, p. 89-I09.

. Eleições na aldeia, ou o Alto Xingu contra o Estado?. Anuário Antropológico, I/20II, p. 3I-54. 
. A flecha do ciúme. O parentesco e seu avesso segundo os Aweti do Alto Xingu. São Paulo: Terceiro Nome, 2015.

VIVEIROS DE CASTRO, Eduardo. Etnologia brasileira. In: MICELLI, Sergio (Org.). O que ler na ciência social brasileira (I970-I995). VolumeI: Antropologia. São Paulo: Sumaré/Anpocs, I999, p. I09-223. 